\title{
How the Batsotso Mourning Rituals Keep the Bereaved Disturbed in Kakamega County, Kenya
}

\author{
Asatsa Stephen, Virginia W. Nyagah, Pamela N. Kaithuru \\ Catholic University of Eastern Africa, Nairobi, Kenya
}

\begin{abstract}
Every community in the world responds to death and loss in unique ways. Funeral customs and ceremonies vary across different cultures worldwide. The study aimed at establishing how these rituals contribute to the psychological disturbance of the bereaved. It also sought to establish the strengths and weaknesses of these rituals on the bereaved. The study focused on establishing and understanding the effects of the Batsotso mourning rituals and ascertaining their possible harmful effects to the bereaved. The research narrowed down to the different rituals performed during the mourning period among the Batsotso people with the aim of generalizing the results to other Kenyan communities. Batsotso is one of the Luhya dialects, a tribe that inhabits Kakamega County in Kenya. The study used descriptive research design. The data was collected by the use of questionnaires, interview, and observation. The target population for this study was 400 families from Butsotso who had experienced death in the last three years. The sample size of 80 participants was selected through simple random sampling. The questionnaires were given to adults and children while the interview guide was administered on adults who had attained at least 50 years of age. The researchers conducted a pilot study where 20 respondents who were not part of the main sample were given the research instruments. This was meant to establish the validity and reliability of the instruments. Results from the study were analyzed using quantitative and qualitative techniques and interpretation presented in form of charts and tables. The Statistical Package for Social Sciences was used in the analysis of quantitative data. The research was guided by three theories. The theories include Bowlbys theory of attachment, Kubler Ross grief theory and Rondos' theory on grief process. The study concluded that there is relationship between the Batsotso mourning rituals and the psychological well-being of the mourners. The study recommends that Batsotso people should practice mourning rituals which have therapeutic and psychological purpose as they help them to cope with death. Batsotso people should further shun the mourning practices which do not have psychological importance as they do not help them to cope with death.
\end{abstract}

Keywords: rituals, grief, Batsotso, mourning

\section{Introduction}

Over a long period of time, different people from different cultures have gone over the mourning process by use of different strategies. Different communities worldwide have unique ways of meeting the emotional needs of the bereaved. For instance, in the Jewish culture, people could take several days after burial, at the burial site. In this culture, the dead bodies were wrapped in clothes before burial as documented in the Holy

Asatsa Stephen, Ph.D. Candidate, Department of Psychology, Catholic University of Eastern Africa.

Virginia W. Nyagah, Ph.D. candidate, Department of Psychology, Catholic University of Eastern Africa.

Pamela N. Kaithuru, Ph.D. candidate, Department of Psychology, Catholic University of Eastern Africa. 
Bible (John11:39). It is also clear that burying the dead was an important part of mourning rituals. In the Far East specifically in India, unique rituals include cremation where the body of the dead is burnt to ashes. The Indians do this to separate the spirit and the bodies of the dead, to allow the spirit go to the spirit world (Clark, 2000). Silverman and Prigerson (2001) discusses how different cultures in Europe conducted funerals. For instance, in Poland a door and windows of the house where someone died were left opened to allow the soul of the deceased to leave. Mirrors were covered with some cloth. Clocks were stopped. Further, a woman, kind of a professional, was called to wash and dress the dead. After washing, the body of the deceased was placed on boards between two chairs or two tables. The body was put in the coffin on the day of burial. There was always someone with the body. The family members and neighbors kept vigil during the night. Traditionally the body was kept in the house for three days. The funeral was held on the third day after the death (Abduljalil, 2004).

African communities too had their own mourning styles. Cottle (2006) examines how the Ndebele people of Zimbabwe mourn their people. He found out that when a person is so close to dying the family makes effort to revive the person by pouring cold water on him or making him inhale smoke from certain herbs. Roos and Toit (2002) examined the rituals used in Ethiopia. They established that an edir is a traditional community organization in which the members assist each other during the mourning process. Members make monthly financial contributions forming the Edir's fund.

In her study, Gichinga (2005) found out that some Kenyan communities for example the Kikuyu responded to death with great fear. In an attempt to be brave, they wear a mask that portrays emotional strength or false front. The feelings are buried beneath the surface and are not allowed expression. With the infiltration of western culture, most of the traditional African mourning rituals were abandoned. Those rituals still practiced have often been condemned blindly without any theoretical support.

This research aimed at establishing a theoretical background to explain both the negative and positive effects of these rituals to the bereaved and their immediate society. The research concentrated in Butsotso south and Butsotso north locations in Kakamega county, which are the two areas dominated by the Batsotso people clans.

Batsotso are believed to have migrated to Kenya from Egypt through Uganda. Batsotso is one of the Luhya dialects inhabiting Kakamega County in Kenya. The Batsotso currently live in Lurambi division. The neighboring Luhya dialects of the Batsotso are Abetakho, Abesukha, Abamarama, Abawanga, Abakabrasi, and Abanyala.

The Batsotso had an established system of government. They were ruled by a king called Omwami. Each clan was ruled by a clan head or elder. The function of the king was to protect his people and maintain peace in the country. The King presided over cases assisted by the clan heads. The King had power over the military and he was the one with the responsibility of declaration and cessation of war. The King himself never participated in war. The king wore a cloak of skins of different animals, a cap, cow hide shoes and a copper bracelet. He had a shrub staff a fly whisk and a traditional stool. The Batsotso used to install their Kings at dawn and kingship was hereditary. The king was buried in a sitting position on a fresh cow hide. The head was covered with a pot which protruded above the grave. After seven days, when the head began to decay, it was pressed into the grave. In the grave was also a small pot of beer with a drinking straw going to the king's mouth. The straw was removed on the seventh day (Were, 1967). This study tested whether the Batsotso mourning rituals had therapeutic value or not. 


\section{Methodology}

Research design is the plan that is used to generate answers to the research problem (O. Mugenda \& A. Mugenda, 2003). The study adopted descriptive research design in order to provide a framework to examine current conditions, trends and status of the study phenomenon. Descriptive research design is more investigative and focuses on a particular variable factor. It is analytical and often singles out a variable factor or individual subject and goes into details and describing them. This research studied the different mourning rituals practised by the Batsotso. The research singled out each ritual, studying how it is practised, the meaning attached to it by the bereaved and whether the bereaved considered it therapeutic or not.

This study targeted 400 families from Butsotso. This is the number of estimated number of families that had experienced death in Butsotso in the past three years (Butsotso South and North locations burial records, 2013). The target population included men, women, girls and boys drawn from five Batsotso clans. A sample size of 80 Participants was targeted. This represents $20 \%$ of the target population. The Participants were selected from five Batsotso clans. This is $25 \%$ of the total number of Batsotso clans and is therefore assumed to be a representative of the 20 targeted clans. The clans were selected from the twenty Batsotso clans by use random sampling technique. The ages of the Participants ranged from at least 13 years and they were to have experienced death of their loved one within the last three years. This is the longest time it takes to complete all the funeral rituals among the Batsotso people. They included men and women, boys and girls. The older generation above 50 years was used to explain the rationale of these rituals. The clans sampled were Abamweche, Abashisiru, Abamatioli, Abashiibo, and Abamwende. The participants from these clans were obtained from the following areas respectively: Ibinzo, Eshisiru, Ematetie, Eshiamboko, and Esumeiya.

\section{Data Analysis}

The study used quantitative and qualitative methods of data analysis. Secondary data was also used to support the findings. Tables, graphs and charts were used.

\section{Results and Discussion}

The study established that $47.27 \%$ of the participants had primary level of education, $30.90 \%$ had Secondary level of education and only $21.81 \%$ were Tertiary education holders. This indicates moderate literacy level of Batsotso people. Thus, the respondents well understood the questionnaires and their responses were assumed to be reliable.

\section{Description of Various Batsotso Mourning Rituals}

Lichienga. Thus is a big fire which is lit in the compound and keep burning continuously pro and after burial. The participants indicated that bonfire is performed so as to unite those who remain behind; to show that they are in good standing with the deceased; to keep the bereaved intact, to keep mourners warm, and to hold funeral discussions around the fire. It can only be lit when the body of the deceased is in the compound of his or her home.

Washing the corpse. The body is taken behind the house, away from the public and a piece of cloth is used to wipe the body, and then the body is anointed and dressed. Washing of corpse is done to remove any dirt so as to send the deceased off when he or she is clean; to confirm that the body was in good condition; to honour the dead, to prove to him or her that though dead, you still value him.

Burial at night. It is a normal burial done at night and is done when one is murdered or when the death is 
not natural so as to curse the killers; it is done to send the spirit of murder away.

Oluveko (shaving). All the close relatives of the departed gather a day or two after burial. The shaving is not done by a special person but each person shaves another. Hair is part of one's body that you can remove to represent personal loss. It is done as an identity for the bereaved members; for warriors it is done to separate the dead and his brevity; to show others that the mourners had a funeral and to separate the dead from the living.

Burial outside compound. It is burying the dead outside the home compound mainly behind the house for those people who have divorced or unwed women. It is done to send the spirit of being unmarried away.

Obukoko. After the burial, the women of the clan of the dead who are married agree on a day they come for this event. Abakoko are part of the family who stay away from home. It is kind of reunion in which an animal is slaughtered. It is done to review what was done in the funeral, pay debts and share the property of the deceased.

Lisabo. The close relatives come back to meet at home of the deceased and an animal is slaughtered. It is done to close the chapter with the deceased; it is the final cerebration to remember the dead. It is usually done one year after burial.

Shinini. This is a small group of relatives who come three to four days after burial. It is an overnight event. It is done to bring the spirits of a person who died away from home back home. It involves visiting the actual place where the person died.

Beating the corpse. It is beating of dead body of a person who has committed suicide; they are beaten to drive the spirit of suicide away. This is done before the body is removed from the spot where the person died.

Remarrying ceremony. Relatives of the deceased gather and the widow chooses from among the brothers of her late husband. It is done so as to get comfort from the new partner. It is also done to give the widow and children of the deceased support and security.

Speaking to the corpse. This is usually done to someone who is believed to have been killed so that he or she can revenge. Also it is done if someone who dies away from home and complicates his journey back home. It is done to ask the dead person when being dressed to flex his or her joints. It is done also to mourn the dead; to curse the people who killed the dead person; to ask for forgiveness from one who was the enemy. It is also a common practise done my mourners as they wail or as they give tribute to the deceased.

Piercing the corpse. A man who die at an advanced age but has never married could be pierced at the back or at his manhood with thorn. It is done to encourage men to get married.

Wailing (Okhwikhula). People cry aloud immediately after death and continue in the entire funeral. It is done to announce the death; to show that one was not responsible for the death; to say good bye to the dead and also to release emotions.

Obuloli. These are tributes said to acknowledge the good things done by the departed. It is done to pay tribute, to show gratitude and to remember his good deeds.

Burial of Banana Stem. It is doing a funeral; service of a person who died and his body cannot be traced. It is done to end searching of the dead and bring the searching to a conclusion.

The respondents were requested to indicate by ticking which rituals they considered not helpful (Non-Therapeutic) to them. More than $50 \%$ of the participants indicated that burial at night, Burial outside compound, Shinini, and beating the corpse, were un-helpful rituals. This indicates that some of the burial ritual performed Batsotso people are un-helpful. The study results indicates that majority of rituals that the participants 
considered helpful such as born fire (Lichienga), washing the dead, shaving, burial of banana stem, Obukoko, Lisabo, remarrying ceremony, speaking to the corpse, piercing the corpse, and wailing, Obuloli (testimony) to great extent were helpful to the Batsotso people as they were less scaring, less oppressive, less expensive, and were considered to less extent anti-religious.

The rituals that the participants considered not helpful such as burial at night, burial outside compound, Shinini, and beating the corpse to great extent were considered unhelpful to the Batsotso people as they were more scaring, more oppressive, more expensive, and were considered to great extent anti-religious. According to Rando (1986), rituals can be used to facilitate memorization and understand internal feelings in order to understand the depth of grief. Kubler's theory advocates for allowing mourning process to be natural without coercing the clients through the stages of grief. This study agrees with this theory and suggests that the rituals that have been classified by participants as non-therapeutic should not be imposed on the clients as doing so would hurt the clients.

Table 1

Ways in Which Morning Rituals Were Unhelpful

\begin{tabular}{|c|c|c|c|c|c|c|c|c|}
\hline \multirow{3}{*}{ Ritual } & \multicolumn{8}{|c|}{ It was unhelpful for me by being: } \\
\hline & \multicolumn{2}{|c|}{ Scaring } & \multicolumn{2}{|c|}{ Oppressive } & \multicolumn{3}{|c|}{ Expensive } & \multirow{2}{*}{$\begin{array}{l}\text { Anti-religious } \\
\% \\
\end{array}$} \\
\hline & $f$ & $\%$ & $f$ & $\%$ & $f$ & $\%$ & $f$ & \\
\hline Born fire (Lichienga) & 0 & 0.00 & 0 & 0.00 & 12 & 21.82 & 0 & 0.00 \\
\hline Washing the dead & 0 & 0.00 & 0 & 0.00 & 0 & 0.00 & 0 & 0.00 \\
\hline Burial at night & 42 & 76.36 & 21 & 38.18 & 11 & 20.00 & 43 & 78.18 \\
\hline Shaving & 7 & 12.73 & 36 & 65.45 & 10 & 18.18 & 13 & 23.64 \\
\hline Burial outside compound & 14 & 25.45 & 35 & 63.64 & 2 & 3.64 & 12 & 21.82 \\
\hline Burial of banana stem & 23 & 41.82 & 9 & 16.36 & 0 & 0.00 & 40 & 72.73 \\
\hline Obukoko & 0 & 0.00 & 0 & 0.00 & 16 & 29.09 & 0 & 0.00 \\
\hline Lisabo & 0 & 0.00 & 0 & 0.00 & 8 & 14.55 & 0 & 0.00 \\
\hline Shinini & 0 & 0.00 & 0 & 0.00 & 10 & 18.18 & 0 & 0.00 \\
\hline Beating the corpse & 53 & 96.36 & 41 & 74.55 & 3 & 5.45 & 49 & 89.09 \\
\hline Remarrying ceremony & 0 & 0.00 & 17 & 30.91 & 23 & 41.82 & 35 & 63.64 \\
\hline Speaking to the corpse & 33 & 60.00 & 12 & 21.82 & 1 & 1.82 & 38 & 69.09 \\
\hline Piercing the corpse & 47 & 85.45 & 43 & 78.18 & 0 & 0.00 & 30 & 54.55 \\
\hline Wailing & 19 & 34.55 & 0 & 0.00 & 0 & 0.00 & 0 & 0.00 \\
\hline Obuloli (Testimony) & 0 & 0.00 & 0 & 0.00 & 0 & 0.00 & 0 & 0.00 \\
\hline
\end{tabular}

Source: Author (2014).

\section{Conclusion and Recommendations}

The study concludes that most of the Batsotso people understand the meaning of their mourning rituals. The rituals that the participants considered not helpful to great extent were considered unhelpful to the Batsotso people as they were more scaring, more oppressive, more expensive, and were considered to great extent anti-religious. Finally, the study concludes that there is relationship between the Batsotso mourning rituals and the psychological well-being of the mourners. The study shows that the therapeutic rituals help the bereaved to resolve their grief which improves on their psychological well-being. The anti-therapeutic rituals could also have a negative impact on the psychological well-being of the bereaved by prolonging the mourning process. The study recommends that grief clients among the Batsotso should avoid anti therapeutic rituals as they are harmful 
to their psychological well-being. The study further recommends the investigation other mourning rituals from the other Kenyan communities to ascertain their therapeutic value.

\section{References}

Abduljalil, J. (2004). Cultural pragmatics: Social performance between ritual and strategy. Sociological Theory, 22(4), 527-573.

Clark, K. (2000). Why angels fall: A journey through Orthodox Europe. London Macmillan.

Cottle, S. (2006). Mediatized rituals: Beyond manufacturing consent. Media, Culture \& Society, 28(3), 411-432.

Gichinga, M. (2005). Counseling in the African context. Nairobi: Gem Counseling Services.

Miller, W. (2000). Integrating spirituality into treatment: Resources for practitioners. Washington D.C.: American Psychological Association.

Mugenda, O., \& Mugenda, A. (2003). Research methods: Quantitative and qualitative approaches. Nairobi: Acts Press.

Roos, V., \& Du Toit, M. (2002). A counselors guide in dealing with trauma, death and bereavement. Pretoria: Tuks Bookshop.

Silverman, G. K., Johnson, J. G., \& Prigerson, H. G. (2001). Preliminary explorations of the effects of prior trauma and loss on risk for psychiatric disorders in recently widowed people. Israel Journal of Psychiatry, 38.

Were, S. G. (1967). Western Kenya, historical texts. Nairobi: EALB. 